\title{
Preliminar evaluation of cytokines in the hepatitis C- schistosomiasis co-infection
}

\author{
Clarice NL Morais, Bruno M Carvalho/ ${ }^{+++}$, Wlademir G Melo, Edmundo PA Lopes*, \\ Ana Lúcia C Domingues*, Norma T Jucá*, Wayner Souza, Frederico GC Abath/ ${ }^{++}$, \\ Silvia ML Montenegro/ ${ }^{+} /++$
}

Centro de Pesquisas Aggeu Magalhães - Fiocruz, Av. Prof. Moraes Rego s/nº, Cidade Universitária, 50670-240 Recife, PE, Brasil *Hospital das Clínicas, Universidade Federal de Pernambuco, Recife, PE, Brasil

Evaluation of hepatic fibrosis is usually performed by histopathological examination of biopsies. However, this is an invasive and potentially dangerous procedure. Several studies have proposed serum biological markers of hepatic fibrosis. This communication evaluates the use of serum cytokines as markers of hepatic fibrosis in hepatitis C, schistosomiasis, and co-infection.

Key words: hepatitis C - cytokines - schistosomiasis - co-infection - fibrosis

Fibrosis is the major cause of mortality and morbidity related to schistosomiasis and hepatitis C (Strauss 2001). Microscopical examination of hepatic biopsy is the gold standard to stage fibrosis, however, it is an invasive procedure and is potentially dangerous. Thus, several studies have emerged in an attempt to develop non invasive methods to evaluate the stage of hepatic fibrosis (Myers et al. 2002, Poynard et al. 2005). The possible synergistic mechanisms present in the association between schistosomiasis and hepatitis $\mathrm{C}$, and leading to severe hepatic disease remains unclear (Kamal et al. 2004).

The main objective of this preliminar study is to evaluate if serum levels of cytokines can be used as biological markers to predict severity of hepatic fibrosis in schistosomiasis and hepatitis $\mathrm{C}$ as isolated diseases or co-infections.

The following groups were composed for the study: hepatosplenic schistosomiasis patients $(n=03)$, hepatitis C patients $(n=23)$, and hepatitis $C$ plus hepatosplenic schistosomiasis patients $(n=11)$. Hepatic biopsies, ultrasonography, stool exams, and blood tests for biological markers of fibrosis were performed. All patients were tested for HIV, hepatitis B, and antibodies against hepatitis C virus.

Diagnosis of hepatitis $\mathrm{C}$ patients was confirmed by detection of viral RNA (Zeuzem et al. 1994) and genotyping (Stuyver et al. 1996). The serum levels of interleukin (IL$13)$, tumor necrosis factor (TNF- $\alpha$ ), and transforming growth factor (TGF- $\beta$ ) were detected by ELISA (enzymelinked immunosorbent assay) kits supplied by R\&D Systems Inc. Minneapolis, MN, US, following the instructions of the supplier.

\footnotetext{
Financial support: CNPq, Fiocruz

${ }^{+}$Corresponding author: silvia@cpqam.fiocruz.br

${ }^{++} \mathrm{CNPq}$ research scholarships

${ }^{+++} \mathrm{CNPq}$, Pibic/Fiocruz fellowship

Received 25 May 2006

Accepted 26 June 2006
}

Statistical analysis was conducted using ANOVA and significance was assumed for a $p$ value $<0.05$.

We compared the IL-13 serum levels between groups, but the differences were not statistically significant (Fig. 1A). In contrast, the levels of serum TNF- $\alpha$ were significantly higher in the co-infected group in comparison to the hepatitis $C$ group $(p=0.001)$ or the central group $(p=$ 0.003 , Fig. 1B). In addition, schistosomiasis patients showed higher TGF- $\beta$ serum levels than the co-infected patients $(\mathrm{p}=0.05$, Fig. $1 \mathrm{C})$.

Few data are available about the immune response of patients co-infected with hepatitis $\mathrm{C}$ and schistosomiasis. IL-13 is considered to be the major fibrogenic mediator in murine schistosomiasis and recent studies in humans associated high levels of this cytokine with the development of more severe hepatic fibrosis (Ribeiro-deJesus et al. 2004), although this was not corroborated by our results, perhaps it may be due to the reduced sample size. Some studies have established a correlation between TNF- $\alpha$ serum levels in hepatitis $C$ patients and the degree of liver inflammation while TGF- $\beta$ serum levels were correlated with liver fibrosis (Neuman et al. 2002). Other studies showed that schistosomiasis may downregulate the stimulatory effect of hepatitis $\mathrm{C}$ virus on Th1 cytokines and this may lead to chronicity of hepatitis $\mathrm{C}$ infection in co-infected patients (El Kady et al. 2004). However, our results showed that serum levels of TNF- $\alpha$, a Th1 cytokine, were significantly higher in the co-infected group than hepatitis $\mathrm{C}$ group. Furthermore, schistosomiasis patients showed significantly higher serum levels of TGF- $\beta$, a known mediator of fibrosis, than co-infected patients suggesting that TGF- $\beta$, is downregulating the production of TNF- $\alpha$.

As the literature on this subject is relatively scarce, this preliminary study contributes to a better understanding of the immunological mechanisms, fibrogenic process, and biological markers. These results suggests that immunoregulation of schistosomiasis-hepatitis $\mathrm{C}$ co-infection is different as far as the diseases are analysed separately. 

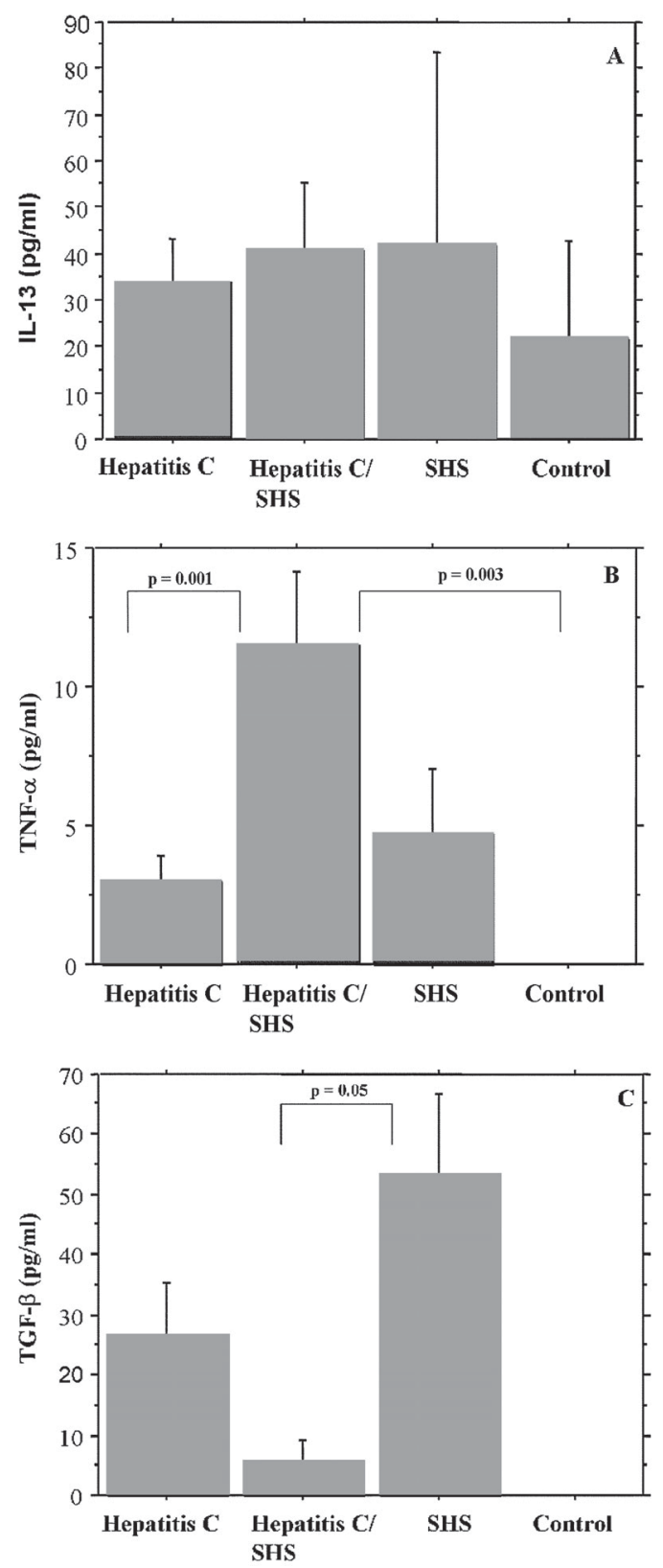

Fig. 1: serum levels of interleukin IL-13 (A), tumor necrosis factor TNF- $\alpha$ (B), and transforming growth factor TGF- $\beta$ (C) in patients with hepatitis $\mathrm{C}$, hepatosplenic schistosomiasis (SHS) and the association of both diseases; $p<0.05$ was considered significant.

\section{ACKNOWLEDGMENTS}

To the technical staff of Serviço de Referência para Diagnóstico em Esquistossomose, CPqAM-Fiocruz, for the valuable help in this work.

\section{REFERENCES}

El-Kady IM, Lofty M, Badra G, El-Masry S, Waked I 2005. Interleukin (IL)-4, IL-10, IL-18 and IFN- $\gamma$ cytokines pattern in patients with combined hepatitis C virus and Schistosoma mansoni infections. Scand J Immunol 61 (Suppl. 1): 87-91.

Kamal SM, Graham CS, He Q, Bianchi L, Tawil AA, Rasenack JW, Khalifa KA, Massoud MM, Koziel MJ 2004. Kinetics of intrahepatic hepatitis $\mathrm{C}$ virus (HCV)-specific $\mathrm{CD}^{+}{ }^{\mathrm{T}}$ cell responses in HCV and Schistosoma mansoni coinfection: relation to progression of liver fibrosis. J Infect Dis 189: 1140-1150.

Myers RP, Ratziu V, Imbert-Bismut F, Charlotte F, Poynard T 2002. Biochemical markers of liver fibrosis: a comparison with historical features in patients with chronic hepatitis C. Am J Gastroenterol 97 (Suppl. 9): 2419-2425.

Neuman MG, Benhamou JP, Bouliere M, Ibrahim A, Malkiewicz I, Asselah T, Martinot-Peignoux M, Shear NH, Katz GG, Akremi R, Benali S, Boyer N, Lecomte L, Le-Breton V, LeGuludec G, Marcellin P 2002. Serum tumour necrosis factor-a and transforming growth factor- $\beta$ levels in chronic hepatitis $\mathrm{C}$ are immunomodulated by therapy. Cytokine 17 (Suppl. 2): 108-117.

Poynard T, Imbert-Bismut F, Munteanu M, Ratziu V 2005. FibroTest-FibroSURE TM: towards a universal biomarker of liver fibrosis? Expert Rev Mol Diagn 5 (Suppl. 1): 15-21.

Ribeiro-de-Jesus A, Magalhães A, Miranda DG, Miranda RG, Araújo MI, Almeida-de-Jesus A, Silva A, Santana LB, Pearce E, Carvalho EM 2004. Association of type 2 cytokines with hepatic fibrosis in human Schistossoma mansoni infection. Infect Immun 72 (Suppl. 6): 3391-3397.

Strauss E. 2001. Hepatite C. Rev Soc Bras Med. Trop 34 (Supl. 1): $69-82$.

Stuyver L, Wyseur A, Arnhem W, Hernandez F, Maertens G 1996. Second-generation line probe assay for hepatitis C virus genotyping. J Clin Microbiol 34 (Suppl. 9): 22592266.

Zeuzem S, Ruster B, Roth WK 1994. Clinical evaluation of a new polymerase chain reaction assay (Amplicor HCV) for detection of hepatitis C virus. Z Gastroenterol 32 (Suppl. 6): $342-347$. 